\title{
GAGASAN PENGADUAN KONSTITUSIONAL DAN PENERAPANNYA DALAM SISTEM KETATANEGARAAN INDONESIA
}

Oleh :

\author{
Ari Asmono*
}

\begin{abstract}
:
Constitutional complaint has an important role in a democratic state of law. constitutional complaint serves as a mechanism for the protection of citizen's constitutional rights are violated by the authorities. with protected constitutional rights of a citizen, then a democratic state of law will be realized very well.
\end{abstract}

Keywords : constitutional complaint, citizen's constitutional rights, constitutional court.

\section{LATAR BELAKANG}

Konstitusi Indonesia (UUD 1945) menyatakan dengan tegas di dalam pasal 1 ayat (3) bahwa Negara Indonesia adalah Negara Hukum (Recthstaats), dimana menurut A.V. Dicey, salah satu unsur yang dimiliki oleh negara hukum adalah pemenuhan akan hak-hak dasar manusia (Fundamental Rights). ${ }^{1}$

Konstitusi sebagai hukum dasar yang utama dari sebuah negara dan merupakan hasil representatif kehendak seluruh rakyat maupun masyarakat, haruslah dilaksanakan dengan sungguh-sungguh di setiap sendi kehidupan berbangsa dan bernegara. Oleh karena itu, prinsip yang timbul adalah bahwa

\footnotetext{
*Pengamat Hukum, ariasmono@gmail.com

${ }^{1}$ Moh. Mahfud M.D. Demokrasi dan Konstitusi di Indonesia (Yogyakarta, 1993), h. 27 - 28 mengutip Oemar Seno Adji, "Prasaran" dalam seminar ketatanegaraan Undang-Undang Dasar 1945 (Jakarta, 1966), h. 24.
}

setiap tindakan, perbuatan, dan/atau aturan dari semua otoritas yang diberi delegasi oleh konstitusi, tidak boleh bertentangan dengan basic rights dan konstitusi itu sendiri. Dengan kata lain, konstitusi harus diutamakan, dan maksud atau kehendak rakyat harus lebih utama daripada wakilwakilnya.

Salah satu bentuk penegasan dari prinsip negara hukum yang dianut oleh negara Indonesia serta perlindungan maupun pemenuhan terhadap hak-hak dasar manusia (Fundamental Rights) seperti yang telah diungkapkan di atas, dan juga sebagai perubahan mendasar pada bidang hukum dan politik di Indonesia adalah terbentuknya lembaga baru yang bernama Mahkamah Konstitusi (MK). Terbentuknya MK itu sendiri adalah merupakan salah satu 
hasil dari amandemen UUD 1945 yang telah dilaksanakan oleh Majelis Permusyawaratan Rakyat (MPR) antara kurun waktu dari tahun 1999 hingga tahun 2002.

Dalam menjalankan fungsinya mengawal konstitusi, berdasarkan Pasal 24C UUD Negara RI Tahun 1945 juncto Pasal 10 Undang-undang No. 24 Tahun 2003 tentang Mahkamah Konstitusi, Mahkamah mempunyai 4 (empat) kewenangan dan 1 (satu) kewajiban.

Pada hakikatnya, fungsi utama MK adalah mengawal supaya kostitusi dijalankan dengan konsisten (the guardian of constitution) dan menafsirkan konstitusi atau UUD (the interpreter of constitution). Dengan fungsi dan wewenang tersebut, keberadaan MK memiliki arti penting dan peranan strategis dalam perkembangan ketatanegaraan dewasa ini karena segala ketentuan atau kebijakan yang dibuat penyelenggara Negara dapat diukur dalam hal konstitusional. Dengan demikian, setiap penyelenggaraan pemerintahan selalu terbangun oleh dan berlandaskan pada prinsip-prinsip dan ketentuan konstitusi. ${ }^{2}$

Sebagai suatu lembaga yang berfungsi sebagai pengawal konstitusi (the guardian of the constitution), apakah dengan kewenangan yang telah dimiliki oleh MK sekarang sudah dapat menjalankan fungsinya dengan baik? Termasukjuga dalam hal perlindungan maupun pemenuhan terhadap hak-hak dasar manusia (Fundamental Rights) di dalam konstitusi.

${ }^{2}$ Mahkamah Konstitusi Republik Indonesia, Cetak Biru Membangun Mahkamah Konstitusi Sebagai Institusi Peradilan Konstitusi Yang Modern Dan Terpercaya, Jakarta, 2004, h. 5-6.
Terhadap hal tersebut, nampaknya masih terdapat satu hal mendasar yang masih mengganjal di benak para pencari keadilan, yaitu belum terbukanya fungsi Mahkamah selaku lembaga yang dapat menampung dan menyalurkan keluh kesah (personal grievance) atau pengaduan konstitusional sebagai upaya hukum yang luar biasa dalam mempertahankan hak-hak konstitusional bagi setiap individu warga negara, atau yang biasanya lebih dikenal dengan istilah constitutional complaint.

Memang dalam rangka membangun suatu mekanisme yang melindungi secara lebih kuat hak-hak konstitusional warga negara, perlu diatur dalam konstitusi tentang hak gugat konstitusional (constitutional complaint), yang kewenangan untuk memutuskannya berada di tangan MK. UUD 1945 pasca amandemen belum memberikan jaminan constitutional complaint, padahal bagi warga negara yang hak-hak dasarnya dilanggar (constitutional injury) senantiasa berhadapan dengan mekanisme apa yang bisa digunakan.

Wacana mengenai kemungkinan diberikannyafungsi pengaduan konstitutisonal (constitutional complaint) kepada Mahkamah Konstitusi bukanlah hal yang baru. Berbagai artikel yang pernah ditulis oleh pakarpakar hukum dan beberapa pertimbangan hukum putusan Mahkamah Konstitusi ${ }^{3}$, secara tersirat telah memberikan sinyalemen bahwa kebutuhan akan fungsi constitutional complaint merupakan suatu keniscayaan yang tidak dapat ditunda-tunda lagi.

${ }^{3}$ Putusan Mahkamah Konstitusi Nomor 001/PUUIV/2006. 
Selain dari beberapa hal diatas, kebutuhan akan pengaduan konstitusional yang sudah mendesak juga dapat dilihat dari beberapa kasus yang muncul di Indonesia. Salah satu kasus yang menarik untuk dilihat yaitu mengenai penerbitan SKB tiga Menteri tentang Pembubaran Ahmadiyah. Bahkan Jaksa Agung Hendarman Supandji saat itu mengatakan bahwa jika ada keberatan dengan SKB tersebut, dipersilahkan menggugat ke MK (Kompas, 10 Juni 2008, hlm.15).

Padahal dari sudut konstitusi MK sama sekali tidak mempunyai kewenangan untuk menilai SKB tersebut. MK hanya berwenang melakukan pengujian Undang-Undang terhadap UUD, memutus sengketa antar lembaga Negara yang kewenangannya diatur di dalam UUD, memutus sengketa hasil pemilu dan memutus pembubaran parpol; sedangkan kewajiban MK adalah memutus pendapat atau dakwaan (impeachment) DPR bahwa Presiden/Wakil Presiden telah melanggar hal-hal tertentu di dalam UUD 1945 atau tidak lagi memenuhi syarat sebagai Presiden/Wakil Presiden. Sehingga dalam hal ini tidak ada kewenangan MK untuk menguji sebuah SKB.

Selain contoh kasus mengenai penerbitan SKB di atas. Masih ada contoh lain mengenai hal ini. Beberapa waktu yang lalu, MK menangani pengujian Pasal 23 Ayat (1) UU No.4 Tahun 2004 tentang Kekuasaan Kehakiman yang pengujiannya diminta oleh Pollycarpus Budihari Priyanto. Pollycarpus merasa hak konstitusionalnya dilanggar karena berdasar putusan PK dia yang telah dibebaskan dalam putusan kasasi dijatuhi hukuman (lagi) oleh MA. Pollycarpus mendalilkan bahwa pengajuan PK oleh kejaksaan atau vonis MA adalah melanggar hak konstitusionalnya, sebab menurut Pasal 263 Ayat (1) UU No.8 Tahun 1981 bahwa PK hanya diajukan oleh terpidana atau ahli warisnya. Tetapi karena MA menggunakan Pasal 23 Ayat (1) UU No.4 Tahun 2004 sebagai dasar membolehkan jaksa mengajukan PK, maka Pollycarpus mengajukan permohonan Judicial Review ke MK agar isi UU No.4 Tahun 2004 dinyatakan inkonstitusional dan tidak mempunyai kekuatan hukum yang mengikat. $^{4}$

Padahal seumpama pun permohonan itu dikabulkan dan Pasal 23 Ayat (1) UU No.4 Tahun 2004 itu dibatalkan oleh MK tetaplah tidak akan ada pengaruhnya bagi hukuman yang harus dijalani oleh Pollycarpus. Artinya dia harus tetap menjalani hukuman seperti putusan PK dari MA. Seperti diketahui, putusan MK tentang Judicial Review berlaku perspektif (ke depan) dan tidak bisa membatalkan putusan MA, karena hal itu bukanlah wewenang MK. Oleh sebab itu, perasaan atau anggapan Pollycarpus bahwa vonis PK dari MA itu telah hak konstitusionalnya lebih tepat diselesaikan melalui pengaduan konstitusional. ${ }^{5}$

Tetapi oleh karena sampai sekarang MK tidak mempunyai wewenang untuk menangani pengaduan konstitusional, maka masalah-masalah tersebut tetap belum dapat diajukan ke MK atau ke jalur penyelesaian

\footnotetext{
${ }^{4}$ Moh. Mahfud M.D. "Reformasi Peradilan harus dituntaskan", Newsletter KHN, Vol. 8, No. 4, Juli-Agustus 2008, h.12.

${ }^{5}$ Ibid.
} 
hukumyanglainnya.Itulahsebabnyamenjadi penting agar dipikirkan kemungkinan menambah kewenangan MK untuk memutus pengaduan konstitusional agar pelanggaranpelanggaran hak konstitusional yang tak ada jalur penyelesaian hukumnya dapat ditangani oleh MK. ${ }^{6}$

Sehingga kemudian ada dua hal yang perlu dibahas, pertama maksud dari konsep pegaduan konstitusional (constitutional complaint), dan kedua perihal penerapan pengaduan konstitusional ini dalam sistem ketatanegaraan Indonesia.

\section{KONSEP PENGADUAN KONSTITUSIONAL (CONSTITUSTIONAL COMPLAINT)}

\section{Sejarah Perkembangan}

Padadasarnyasejarahkelahirangagasan pengaduan konstitusional atau yang biasa di negara lain dikenal dengan constitutional complaint berkaitan langsung dengan, bahkan merupakan konsekuensi logis dari gagasan negara hukum. Secara ringkas, konstruksi teoritisnya sebagai berikut : ciri pertama dari negara hukum modern adalah constitutionalism, yang berarti penyelenggaraan kehidupan bernegara didasarkan atas dan (karena itu) tidak boleh bertentangan dengan konstitusi. Oleh karena itu maka konstitusi benar-benar terjelma atau ditaati dan dilaksanakan dalam praktik, bukan sekedar sebagai dokumen aspirasional belaka. Untuk menjamin bahwa konstitusi benar-benar ditaati dan dilaksanakan dalam praktiknya lahirlah gagasan membentuk

\footnotetext{
${ }^{6}$ Ibid.
}

Mahkamah Konstitusi. $^{7}$

Dengan demikian, fungsi Mahkamah Konstitusi adalah constitutional review (pengujian konstitusional), yang mencakup baik pengujian konstitusionalitas norma hukum maupun konstutisionalitas tindakan atau perbuatan. Contitutional review memiliki dua tugas utama. Pertama, menjaga berfungsinyaproses-proses demokrasidalam hubungan saling mempengaruhi antara lembaga legislatif, eksekutif, dan yudisiil - yang dengan kata lain berarti mencegah perebutan kekuasan oleh salah satu cabang kekuasaan negara dengan mengorbankan cabang-cabang kekuasaan negara lainnya. Kedua, melindungi hak-hak atau kehidupan pribadi warga negara dari pelanggaran yang dilakukan oleh salah satu cabang kekuasaan negara. ${ }^{8}$

Sehingga tepatlah jika Brown dan Wise mengatakan bahwa gagasan membentuk Mahkamah Konstitusi adalah upaya untuk menegakkan prinsip-prinsip negara hukum dan memberi perlindungan maksimum terhadap demokrasi dan hak-hak dasar warga negara. Dilihat dari perspektif ini, maka pemberian kewenangan kepada mahkamah konstitusi untuk memutus perkara constitutional complaint adalah sebagai bagian dari pelaksanaan fungsi mahkamah konstitusi untuk melaksanakan

${ }^{7}$ I Dewa Gede Palguna, Pengaduan Konstitusional (constitutional complaint) dan Perlindungan Hak-hak Konstitusional Warga Negara, disampaikan pada Seminar "Pengaduan Konstitusional (Constitutional Complaint) dan Kewenangan Mahkamah Konstitusi Republik Indonesia dalam Penegakan Hak-Hak Konstitusional Warga Negara" yang diselenggarakan oleh Sekretariat Jenderal dan Kepaniteraan Mahkamah Konstitusi bekerjasama dengan Fakultas Hukum Universitas Udayana, 12 Desember 2009.

${ }^{8}$ Ibid. 
constitutional review, yang tujuannya adalah bukan hanya memberikan perlindungan maksimum bagi hak-hak konstitusional warga negara tetapi juga bagi demokrasi. ${ }^{9}$ Secara umum, demikianlah awal permulaan munculnya gagasan constitutional complaint sebagai salah satu wewenang mahkamah konstitusi di dunia.

Munculnya constitutional complaint ini juga tidak terlepas dari belum optimalnya mekanisme - mekanisme perlindungan terhadap warga negara yang telah ada dalam fungsinya memberikan perlindungan terhadap hak-hak warga negara, beberapa mekanisme tersebut adalah citizen lawsuit dan onrechtmatige overheidsdaad. Mekanisme - mekanisme tersebut memang pada dasarnya telah berfungsi dengan baik, sesuai dengan dasar pemikiran awal terbentuknya gagasan dari mekanisme tersebut. Namun dalam beberapa hal, hak dari warga negara masih belum tercover.

Selanjutnya akan sedikit dijelaskan mengenai kedua mekanisme tersebut di atas, yaitu citizen lawsuit dan onrechtmatige overheidsdaad.

\section{Citizen Lawsuit}

Citizen Lawsuit atau Gugatan Warga Negara terhadap penyelenggara Negara sebenarnya tidak dikenal dalam sistem hukum Civil Law sebagaimana yang diterapkan di Indonesia. Citizen lawsuit sendiri lahir di negara-negara yang menganut sistem hukum Common Law, dan dalam sejarahnya Citizen Lawsuit pertama kali diajukan terhadap permasalahan

\footnotetext{
${ }^{9}$ Ibid.
}

lingkungan. Namun pada perkembangannya, Citizen Lawsuit tidak lagi hanya diajukan dalam perkara lingkungan hidup, tetapi pada semua bidang dimana negara dianggap melakukan kelalaian dalam memenuhi hak warga negaranya. Beberapa karakteristik dari gugatan citizen lawsuit antara lain :

1. Tergugat dalam CLS adalah Penyelenggara Negara, Mulai dari Presiden dan Wakil Presiden sebagai pimpinan teratas, Menteri dan terus sampai kepada pejabat negara di bidang yang dianggap telah melakukan kelalaian dalam memenuhi hak warga negaranya. Dalam hal ini pihak selain penyelenggara negara tidak boleh dimasukkan sebagai pihak baik sebagai Tergugat maupun turut tergugat, karena inilah bedanya antara CLS dengan gugatan warga negara. Jika ada pihak lain (individu atau badan hukum) yang ditarik sebagai Tergugat/Turut Tergugat maka Gugatan tersebut menjadi bukan Citizen Lawsuit lagi, karena ada unsur warga negara melawan warga negara. Gugatan tersebut menjadi gugatan biasa yang tidak bisa diperiksa dengan mekanisme Citizen Lawsuit

2. Perbuatan Melawan Hukum yang didalilkan dalam Gugatan adalah kelalaian Penyelenggara Negara dalam pemenuhan hak-hak warga negara. Dalam hal ini harus diuraikan bentuk kelalaian apa yang telah dilakukan oleh negara dan hak warga negara apa yang gagal dipenuhi oleh Negara. Penggugat harus membuktikan 
bahwa Negara telah melakukan Perbuatan Melawan Hukum tersebut, sebagaimana gugatan perdata biasa.

3. Penggugat adalah Warga Negara, yang bertindak mengatasnamakan warga negara. Penggugat dalam hal ini cukup membuktikan bahwa dirinya adalah warga negara Indonesia. Berbeda dengan class action, Penggugat tidak harus merupakan kelompok warga negara yang dirugikan secara langsung oleh negara, oleh karena itu Penggugat tidak harus membuktikan kerugian materiil apa yang telah dideritanya sebagai dasar gugatan, berbeda dengan gugatan perdata biasa. Selain itu Penggugat secara keseluruhan adalah mewakili Warga Negara Indonesia, tidak perlu dipisahpisah menurut kelompok kesamaan fakta dan kerugian sebagaimana dalam Gugatan Class Action.

4. Petitum gugatan Citizen Lawsuit harus berisi permohonan agar negara mengeluarkan suatu kebijakan yang mengatur umum (Regeling) agar perbuatan melawan hukum berupa kelalaian dalam pemenuhan hak warga negara tersebut di masa yang akan datang tidak terjadi lagi.

5. Petitum Gugatan Citizen Lawsuit tidak boleh berisi pembatalan atas suatu Keputusan Penyelenggara Negara (Keputusan Tata Usaha Negara) yang bersifat konkrit individual dan final karena hal tersebut merupakan kewenangan dari peradilan TUN.
6. Petitum Gugatan Citizen Lawsuit juga tidak boleh memohon pembatalan atas suatu Undang-undang (UU) karena itu merupakan kewenangan dari Mahkamah Konstitusi (MK). Selain itu Citizen Lawsuit juga tidak boleh meminta pembatalan atas Peraturan perundang-undangan di bawah Undang-undang (UU) karena hal tersebut merupakan kewenangan Mahkamah Agung (MA) sebagaimana kinitelah diatur dalam PERMAtentang Judicial Review peraturan perundangundangan di bawah undang-undang

Onrechtmatige Overheidsdaad (perbuatan melawan hukum oleh penguasa)

Penguasa sebagai badan hukum publik mempunyai 2 jenis tugas kewajiban yakni tugas kewajiban yang terletak dalam lapangan hukum publik dan tugas yang bersifat hukum privat. Dalam menjalankan tugasnya yang bersifat hukum privat penguasa telah ikut serta dalam pergaulan masyarakat seperti badan - badan hukum lainnya.

Bilamana penguasa ikut serta dalam pergaulan masyarakat sebagai orang partikelir maka sebagai halnya dengan orang partikelir tersebut dapat dipertanggungjawabkan berdasarkan pasal 1365 Burgerlijk Wetbook (B.W).

Dalam hal demikian itu maka selama belum ada peradilan administrasi, penyelesaiannya masuk wewenang Pengadilan Umum (hakim perdata). Adapun dasar wewenang hukum perdata 
untuk mengadili tuntutan-tuntutan yang didasarkan atas perbuatan melawan hukum dari penguasa terletak dalam Pasal 2 Rechterlijke Organisatie (selanjutnya disingkat R.O) dalam hubungannya dengan ketentuan dalam Pasal 24 U.U.D.R.I.

Perlu dikemukakan bahwa mengenai ketentuan dalam Pasal 2 R.O tersebut dikenal pendapat yang luas dan pendapat yang sempit yang menganut pendapat yang sempit adalah antara lain Thorbecke yang mengajarkan, bahwa penyelesaian suatu sengketa hanyalah termasuk wewenang hakim perdata, bilamana dasarnya terletak dalam hubungan hukum keperdataan, sedang pendapat yang luas yang dianut antara lain adalah oleh Buys, mengajarkan bahwa penyelesaian suatu sengketa termasuk wewenang hakim perdata, bilamana sengketanya mengenai hak milik atau hak-hak yang terbit dari hak milik, mengenai hak tagih atau hak keperdataan, tanpa mempersoalkan apakah dasar dari persengketaan tersebut terletak dalam hubungan hukum keperdataan ataukah terletak dalam hubungan hukum publik. Pendapat yang luas tersebut dianut oleh kebanyakan sarjana dan sekarang telah diterima oleh doktrin.

Beberapa keputusan Mahkamah Agung R.I memberikan dasar hukum, bahwa sementara belum dibentuk suatu peradilan administrasi, pengadilan umumlah yang berwenang mengadili tuntutan ganti kerugian karena kerugian yang diderita oleh seseorang karena perbuatan melawan hukum oleh penguasa.
Pertama-tama Keputusan Pengadilan Negeri Jakarta tanggal 15 Juli 1953 No. 1278/1953 G. yang mempertimbangkan antara lain sebagai berikut : "Menurut pasal 2 R.O. maupun pasal 101 U.U.D.S.R.I., hakim berkuasa memeriksa dan mengadili perkara terhadap pemerintah". Dalam tahun 1974 menyusul lagi sebuah Keputusan Mahkamah Agung R.I tanggal 26 November 1974 Reg. No. 339K/Sip/1973 dengan mempertimbangkan antara lain sebagai berikut : "Menurut yurisprudensi onrechtmatige overheidsdaad Pengadilan Negeri berwenang untuk mengadilinya".

\section{Unsur dan Karakter}

Dalam bahasan ini akan membahas mengenai unsur dan karakter dari mekanisme constitutional complaint yang ada di beberapa negara. Namun dikarenakan terbatasnya ruang dan waktu, maka negara yang akan dibahas mengenai unsur dan karakter dari mekanisme constitutional complaint ini adalah Negara Jerman.

\section{Jerman}

Mahkamah Konstitusi Jerman terdiri atas dua panel dan masing-masing panel beranggotakan delapan orang hakim [Pasal 2 ayat (1) dan (2) BVerfGG]. Masingmasing panel ini memiliki kewenangan atau kompetensinya masing-masing. Panel yang pertama berwenang memeriksa perkaraperkara pengujian undang-undang dan constitutional complaintdiluarconstitutional complaint yang diatur dalam Pasal $91^{10}$

10 Pasal 91 BVerfGG mengatur tentang pengaduan konstitusional yang diajukan oleh komune atau asosiasi komune. 
dan pengaduan-pengaduan yang berada dalam ranah undang-undang pemilihan umum. Sedangkan Panel Kedua berwenang memeriksa perkara-perkara penghilangan hak-hak dasar, inkonstitusionalitas partai politik, pengaduan mengenai keputusankeputusan Bundestag yang berkaitan dengan keabsahan pemilihan umum atau pengisian atau kekosongan suatu jabatan deputi di Bundestag, impeachment Presiden Federal oleh Bundestag atau oleh Bundesrat, penafsiran Grundgesetz ${ }^{11}$ (selanjutnya disingkat GG) dalam hal terjadi sengketa mengenai ruang lingkup hak dan kewajiban dari suatu organ Federal tertinggi atau dari pihak-pihak lain terkait yang hakhaknya diberikan oleh GG atau oleh rules of procedure dari suatu organ Federal tertinggi, ketidaksepakatan mengenai hak dan kewajiban Federasi dan Negara Bagian (Länder) - khususnya dalam implementasi suatu undang-undang Federal oleh Negara Bagian dan dalam pelaksanaan supervisi Federal sebagaimana diatur dalam Pasal 93 ayat (1) (3) dan Pasal ayat (4) kalimat kedua GG, sengketa lain yang melibatkan hukum publik - antara Federasi dan Negara Bagian, antar-sesama Negara Bagian atau di dalam suatu Negara Bagian kecuali jika ada jalan bagi pelaksanaan kewenangan pengadilan lain, impeachment hakim Federal dan hakim Negara Bagian, dalam hal terjadi keragu-raguan apakah suatu ketentuan hukum internasional publik merupakan bagian integral dari hukum Federal serta apakah ketentuan tersebut secara langsung melahirkan hak dan

\footnotetext{
11 Undang-Undang Dasar Jerman
}

kewajiban terhadap perorangan - jika putusan atas persoalan demikian dimintakan oleh suatu pengadilan, perkara mengenai kelangsungan suatu undang-undang sebagai undang-undang Federal, serta constitutional complaint yang diatur dalam Pasal 91 Bundesverfassungsgerichtsgeset ${ }^{12}$ (selanjutnya disingkat BVerfGG) dan pengaduan-pengaduan yang berada di ranah undang-undang pemilihan umum (Pasal 14 ayat (1) dan (2) BVerfGG). Kedua Panel itu kemudian menunjuk beberapa chamber yang terdiri atas tiga orang hakim untuk masa kerja satu tahun. Komposisi chamber ini hanya boleh dipertahankan untuk jangka waktu maksimum tiga tahun (Pasal 15a ayat (1) BVerfGG).

Pada mulanya, konstitusi Jerman atau GG tidak mengatur secara eksplisit kewenangan MK Jerman untuk memutus dan menangani perkara constitutional complaint atau constitutional complaint ini. Kewenangan tersebut secara tegas baru diberikan kemudian, sebagaimana dapat dilihat didalam Pasal 93 ayat (1) GG saat ini. Pasal 93 ayat (1) GG selengkapnya menyatakan demikian:

\section{The Federal Constitutional Court} decides:

1. on the interpretation of this Constitution in the event of disputes concerning the extent of the rights and duties of a highest federal body or other parties concerned who have been vested with rights of their own by this Constitution or

12 Undang-Undang Mahkamah Konstitusi Jerman 
by rules of procedure of a highest federal body;

2. in case of differences of opinion or doubts on the formal and material compatibility of federal law or State law with this Constitution, or on the compatibility of State law with other federal law, at the request of the Government, of a State government, or of one third of the House of Representatives [Bundestag] members;

2a. in case of differences of oninion on the compatibility of federal law with Article 72 II, at the request of the Senate [Bundesrat], of a State government, or of a State parliament ${ }^{13}$

3. in case of differences differences of opinion on the rights and duties of the Federation and the States [Länder], particularly in the execution of federal law by the States [Länder] and in the exercise of federal supervision;

4. on other disputes involving public law, between the Federation and the States [Länder], between different States [Länder] or within a State [Land], unless recourse to another court exists;

4a. oncomplaints ofunconstitutionality, being filed by any person claiming that one of his basic rights or one of his rights under Article 20 IV or

13 Ketentuan pada Ayat (1) 2.a ini dimasukkan pada Amandemen ke-42 (27 Oktober 1994). under Article 33, 38, 101, 103 or 104 has been violated by public authority; ${ }^{14}$

4b. on complaints of unconstitutionality filed by communes or associations of communes on the ground that their right to self-government under Article 28 has been violated by a statute other than a State statute open to complaint to the respective State constitutional court; ${ }^{15}$

5. in other cases provided for in this Constitution.

Selanjutnya mengenai Hak Mengajukan Permohonan, pada dasarnya yang dapat mengajukan adalah perorangan jika hakhak yang dilanggar oleh suatu pejabat publik (public authority) adalah hak-hak dasar atau hak-hak yang diatur dalam Pasal 20IV atau Pasal 33, 38, 101, 103, atau 104 GG. Begitu juga menurut Pasal 90 ayat 1 BVerfGG, "setiap orang" berhak untuk mengajukan permohonan, sejauh ia mampu memegang hak-hak dasar. Namun dalam perkembangannya diatur juga selain perorangan. Hak mengajukan permohonan bagi badan-badan hukum swasta diatur dalam Pasal 19 ayat 3 GG, sedangkan Gemeinde $^{16}$ diatur dalam Pasal 28GG, persekutuan keagamaan dalam Pasal 140 GG.

Selanjutnya berkaitan dengan subjek pengaduan, dalam hal ini yang menjadi

\footnotetext{
14 Ayat ini dimasukkan pada Amandemen ke-19 (29 Januari 1969).

15 Ayat ini dimasukkan pada Amandemen ke-19 (29 Januari 1969).

16 Semacam distrik pemerintahan di Jerman. Kirakira setingkat dengan kelurahan.
} 
subjek haruslah merupakan suatu tindakan kekuasaan kenegaraan publik di Jerman. Dimana tindakan ini nantinya harus menyinggung bagian-bagian dari hakhak asasi atau hak-hak yang disetarakan dengannya. Termasuk di dalamnya semua tindakan kekuasaan Jerman secara langsung ataupun tidak langsung, sepanjang tindakantindakan tersebut menimbulkan dampak hukum di lingkup dalam negeri sebagaimana ditur dalam BVerfGE ${ }^{17} 77$.

Ketentuan selanjutnya, yang sekaligus merupakan bagian dari hukum acara mengenai constitutional complaint, diatur dalam BVerfGG, Pasal 90 sampai dengan Pasal 95. Berdasarkan ketentuan Pasal 90 $B V e r f G G$ tersebut dapat disimpulkan bahwa pada dasarnya constitutional complaint baru dapat diajukan jika tidak tersedia upaya hukumlagiatau semuaupayahukumyangada telah dilalui (exhausted). Namun, ketentuan demikian dapat dikesampingkan, artinya MK Jerman dapat segera menjatuhkan putusan atas suatu perkara constitutional complaint meskipun semua upaya hukum yang tersedia belum ditempuh, jika hal itu pengaduan itu "mengandung relevansi umum" (of general relevance) atau jika penyelesaian melalui pengadilan lain ditempuh terlebih dahulu akan menimbulkan suatu kerugian serius dan tak terhindarkan pada pihak pemohon pengaduan (complainant). Pengaduan konstitusional yang diajukan ke MK Jerman tidak mempengaruhi hak pemohon pengaduan untuk mengajukan constitutional complaint ke mahkamah konstitusi Negara

\footnotetext{
17 Kumpulan keputusan-keputusan Mahkamah Konstitusi Federal
}

Bagian sesuai dengan konstitusi Negara Bagianyang bersangkutan.Alasan pengajuan constitutional complaint harus menjelaskan hak-hak yang didalilkan telah dilanggar maupun dan perbuatan atau kelalaian dari organ atau pejabat yang didalilkan telah melakukan pelanggaran itu. Ketentuan tersebut diatur dalam Pasal 92 BVerfGG. Selanjutnya, secara rinci Pasal 93 BVerfGG, mengatur tentang jangka waktu pengajuan constitutional complaint akibat suatu keputusan dan pengaduan yang ditujukan terhadap suatu kebijaka atau terhadap suatu perbuatan yang dilakukan oleh pejabat yang berwenang serta akibat hukum yang berkait dengan jangka waktu dimaksud.

Berdasarkan seluruh uraian tentang constitutional complaint yang berlangsung di Jerman, beberapa hal yang penting untuk digarisbawahi dalam hal unsur dan karakter constitutional complaint adalah:

1. Pengaduan konstitusional adalah bagian dari masalah pengujian konstitusional (constitutional review).

2. Pengaduan konstitusional pada prinsipnya baru dapat dilakukan jika semua upaya hukum yang tersedia sudah dilalui (exhausted), hanya dalam kasus-kasus tertentu keharusan untuk melalui semua upaya hukum tersebut dapat dikecualikan - yaitu jika MK Jerman berpendapat bahwa pengaduan itu mengandung relevansi yang bersifat umum atau jika keharus untuk menempuh seluruh upaya hukum terlebih dahulu itu justru akan membawa kerugian serius dan tak 
terhindarkan pada pihak pemohon pengaduan.

3. Pihak yang dapat mengajukan permohonan constitutional complaint adalah individu atau perorangan, untuk pelanggaran terhadap hak-hak dasar atau hak-hak yang ditentukan secara khusus dalam GG, dan komune atau asosiasi komune, untuk pelanggaran yang berkait dengan hakhak komune untuk menyelenggarakan pemerintahan sendiri.

4. Objek pengaduan dapat ditujukan kepada perbuatan atau kelalaian yang dilakukan oleh pejabat publik (baik di tingkat Federal maupun Negara Bagian), putusan pengadilan, maupun undang-undang.

5. Akibat hukum jika suatu constitutional complaint dikabulkan adalah bermacam-macam tergantung pada objek pengaduan:

- jika pengaduan ditujukan terhadap perbuatan atau kelalaian pejabat publik, maka MK Jerman akan menyatakan ketentuan GG yang dilanggar oleh perbuatan atau kelalaian itu dan pada saat yang sama juga dapat menyatakan bahwa pengulangan perbuatan atau kelalaian serupa merupakan pelanggaran terhadap GG;

- jika pengaduan ditujukan terhadap suatu keputusan pengadilan, maka MK Jerman akan membatalkan keputusan itu, sementara jika pengaduan yang dikabulkan itu sebelum semua upaya hukum yang tersedia dilalui maka MK Jerman akan mengembalikan persoalan tersebut kepada pengadilan yang memiliki kompetensi untuk mengadilinya;

- Jika pengaduan itu ditujukan terhadap suatu undang-undang, maka MK Jerman akan menyatakan undang-undang itu batal (null and void). Ketentuan ini juga berlaku constitutional complaint yang ditujukan terhadap putusan pengadilan yang pengambilan putusan itu didasarkan pada undang-undang yang bertentangan dengan GG.

\section{KEMUNGKINAN PENERAPAN PENGADUAN KONSTITUSIONAL DI INDONESIA}

\section{Keadaan Yang Mendesak}

Sebagai hukum yang tertinggi, tentu sebuah konstitusi harus dihormati. Tidak boleh ada satu pun ketentuan hukum, tindakan penyelenggara negara atau penguasa, bahkan tindakan warga negara yang boleh bertentangan dengan konstitusi tersebut. Sesuai dengan inti ajaran paham konstitusionalisme, bahwa tidak ada pula ketentuan hukum dan tindakan negara yang boleh melanggar hak konstitusional warga negara, kecuali hal tersebut memang diperbolehkan oleh konstitusi atau undang- 
undang sebagai bentuk pembatasan. Karena jika suatu ketentuan hukum atau tindakan negara telah melanggar hak konstitusional warga negara, maka hal tersebut dapat dikatakan inkonstitusional.

Secara kenyataan sangat dimungkinkan terjadi adanya aturan ataupun instrumen hukum serta tindakan penyelenggara negara ataupun tindakan penguasa yang nyatanyata telah melanggar hak konstitusional warga negara. Aturan hukum memiliki peluang bertentangan dengan konstitusi, hal ini terutama dikarenakan hukum adalah produk politik yang dipengaruhi konfigurasi politik saat pembentukannya yang mungkin memiliki kecenderungan yang tidak sesuai dan bahkan bertentangan dengan konstitusi.

Terhadap pelanggaran oleh ketentuan hukum, terdapat mekanisme pengujian konstitusionalitas aturan hukum atau biasanya disebut dengan judicial review, khususnya undang-undang. Melalui mekanisme tersebut norma yang dipandang telah melanggar hak konstitusional warga negara diuji dalam suatu forum pengadilan. Jika terbukti melanggar hak konstitusional berarti bertentangan dengan konstitusi dan akan dinyatakan tidak memiliki kekuatan hukum yang mengikat.

Salah satu dari prinsip negara hukum adalah pemerintahan berdasarkan undangundang. Artinya, setiap penyelenggara harus memiliki dasar hukum. dengan adanya mekanisme pengajuan pengujian perundangundanganyang berpucak pada konstitusi, sesungguhnya dapat dicegah adanya tindakan atau keputusan penyelenggara negara yang melanggar hak konstitusional warga negara.

Namun hal tersebut juga tidak menutup kemungkinan untuk terjadinya tindakan atau keputusan penyelenggara negara yang melanggar hak konstitusional warga negara. Hal ini dapat terjadi paling tidak dikarenakan oleh tiga sebab. Pertama, pejabat penyelenggara negara sebagai pemegang kekuasaaan tertentu memiliki kesempatan penyalahgunaan kekuasaan, baik dikerenakan oleh kesengajaan ataupun dikarenakan oleh kelalaian. Kedua, terdapat banyak ketentuan hukum yang dalam pelaksanaannya membutuhkan penafsiran dan penyesuaian dengan kondisi nyata dari aparat pelaksana. penafsiran yang dilakukan oleh aparat dapat saja keliru dan mengakibatkan terjadinya pelanggaran hak konstitusional warga negara. Ketiga, salah satu ciri negara modern adalah negara kesehjateraan yang memberikan kebebasan bertindak kepada pemerintah untuk meningkatkan kesejahteraan rakyat. Biasanya tindakan yang dilakukan tersebut dimaksudkan untuk meningkatkan pembangunan ekonomi yang tidak jarang berdampak pada terjadinya pelanggaran hak konstitusional wagra negara.

Pelanggaran hak konstitusional warga negara dalam ketentuan aturan hukum dapat diluruskan melalui mekanisme judicial review. Namun pertanyaan selanjutnya adalah mekanisme apa yang dapat ditempuh terhadap tindakan atau keputusan penyelenggara negara yang melanggar hak konstitusional warga negara?. Dalam beberapa aspek memang dapat digunakan 
mekanisme melalui peradilan biasa, terutama terhadap pelanggaran yang terjadi karena penyalahgunaan wewenang dan penafsiran yang keliru. Hal itu dapat dilakukan baik melalui peradilan pidana, perdata, maupun TUN (Tata Usaha Negara).

Namun proses peradilan tersebut masih tetap memiliki celah, yaitu dasar hukum yang digunakan untuk mengadili adalah hanya pada tingkat undang-undang ke bawah. Bukankah hak konstitusional wagra negara dijamin oleh konstitusi? Bagaimana jika tidak ada ketentuan hukum yang dilanggar, tetapi nyata-nyata melanggar hak konstitusional warga negara? Bagaimana juga jika terjadi kesalahan penafsiran dan penerapan hukum oleh hakim dalam proses peradilan yang dilalui dari tingkat pertama hingga terakhir?.

Pertanyaan-pertanyaan tersebut mulai muncul dikarenakan pentingnya perlindungan terhadap hak konstitusional warga negara, terutama hak dan kebebasan dasar yang dijamin konstitusi. Di beberapa negara, terhadap tindakan atau keputusan penyelenggara negara yang melanggar hak tersebut dapat diajukan dengan pengaduan konstitusional yang notabene menjadi salah satu wewenang dari Mahkamah Konstitusi sebagai pengawal konstitusi.

Namun saatini, kewenangan Mahkamah Konstitusi (MK) RI tidak mencangkup memutus pengaduan konstitusional. Padahal dalam prakteknya, Mahkamah Konstitusi banyak menerima perkara pengaduan yang dapat dikategorikan sebagai pengaduan konstitusional, sehingga perkara pengaduan tersebut tidak dapat diproses dan dikembalikan dengan penjelasan mengenai kewenangan yang dimiliki oleh Mahkamah Konstitusi.

Sebagai contoh, pernah beberapa perkara pengaduan konstitusional diajukan ke Mahkamah Konstitusi, namun dinyatakan "tidak dapat diterima" (niet ontvankelijk verklaard) dengan alasan Mahkamah Konstitusi RI tidak berwenang untuk mengadilinya. Beberapa kasus tersebut adalah Perkara No. 016/PUU-I/2003, Perkara No. 061/PUU-II/2004 dan Perkara No. 004/PUU-III/2005.

\section{Hambatan dan Peluang Yuridis}

Bebicara mengenai kemungkinan Indonesia untuk mengadopsi atau menerapkan mekanisme pengaduan konstitusional dalam sistem ketatanegaraan Indonesia menjadi sangat berarti untuk diberi perhatian sungguh-sungguh, sebagaimana telah dijelaskan sebelumnya mengenai alasan-alasan serta keadaan yang menuntut akan mekanisme ini.

Namun, karena Pasal 24C ayat (1) dan (2) UUD 1945 telah secara limitatif menentukan kewenangan Mahkamah Konstitusi, maka penambahan kewenangan hanya mungkin dilakukan dengan melakukan perubahan terhadap ketentuan UUD 1945 dimaksud. Padahal, untuk melakukan perubahan terhadap UUD 1945 tidaklah mudah. Sebab, untuk dapat diagendakan dalam Sidang MPR saja, usul perubahan itu harus diajukan oleh sekurang-kurangnya 1/3 dari jumlah anggota MPR. Itu pun harus 
disertai alasan yang jelas. ${ }^{18}$

Secara teoretik maupun praktik, sebagaimana telah dijelaskan pada uraian sebelumnya dan sebagaimana tampak dalam praktik di Jerman, pengaduan konstitusional adalah bagian dari materi pengujian konstitusionalitas - dalam hal ini, terutama pengujian konstitusionalitas tindakan (atau kelalaian) yang mengakibatkan terlanggar atau dirugikannya hak-hak konstitusional warga negara. Jika hal ini dihubungkan dengan Pasal 24C ayat (1) UUD 1945, maka constitutional complaint, secara terbatas, dapat dimasukkan ke dalam materi pengujian undang-undang. Bahkan, prosedur pengujian undang-undang yang berlaku di Indonesia saat ini, berdasarkan UUMK, di Jerman merupakan bagian dari prosedur pengaduan konstitusional - dalam hal ini, pengaduan konstitutional terhadap konstitusionalitas undang-undang. ${ }^{19}$ Dikatakan secara terbatas karena yang hendak diadukan adalah terbatas pada tindakan atau kelalaian pejabat publik (sehingga merugikan hak-hak konstitusional warga negara) yang lahir dari kekeliruan menafsirkan norma undang-undang.

Konkretnya, permohonan pengaduan konstitusional itu tetap dikonstruksikan sebagai permohonan pengujian undangundang, namun substansinya permohonan itu bukanlah mempersoalkan konstitusionalitas norma undang-undang yang dimohonkan pengujian tersebut melainkan konstitusionalitas tindakan pejabat publik (atau tidak dilakukannya tindakan oleh pejabat publik) sebagai akibat penafsiran

18 Pasal 37 ayat (1) dan (2) UUD 1945

19 Silakan lihat kembali Pasal 92 dan Pasal 93 ayat (3) $B \operatorname{VerfGG}$. yang keliru terhadap norma undang-undang itu sehingga mengakibatkan terlanggar atau dirugikannya hak-hak konstitusional warga negara. Sehingga yang diminta dalam petitum permohonan itu adalah pernyataan dari Mahkamah Konstitusi bahwa tindakan atau kelalaian pejabat publik itu bertentangan dengan undang-undang dasar.

\section{Kesimpulan}

a. Mekanisme constitutional complaint di Negara Jerman pada khususnya dan di beberapa negara lainnya pada umumnya, muncul dikarenakan dilatarbelakangi oleh beberapa hal. Pertama, gagasan tersebut merupakan konsekuensi dari salah satu ciri negara hukum, dimana salah satu ciri dari negara hukum ini adalah constitutionalism. Kedua, gagasan tersebut juga merupakan konsekuensi dari salah satu cirinegara yang lainnya, yaitu perlindungan terhadap hak dasar warga negara. Ketiga, gagasan ini juga tidak terlepas dari belum optimalnya mekanisme-mekanisme yang telah ada yang betujuan memberikan perlindungan terhadap hak-hak warga negara.

b. Di Jerman, Mahkamah Konstitusi Jerman memiliki kewenangan untuk menangani dan memutus perkara constitutional complaint. Pengaturan mengenai constitutional complaint ini secara garis besar bisa dilihat dalam GG, BVerfGG, dan BVerfGE. Mengenai ketentuan siapa saja yang berhak mengajukan permohonan pada 
dasarnya adalah perorangan, yang diatur dalam Pasal 20IV atau Pasal 33, 38, 101, 103, atau 104 GG. Mengenai subjek pengaduan dari constitutional complaint, pada dasarnya sesuai dengan BVerfGE 77 subjeknya adalah suatu tindakan kekuasaan kenegaraan publik yang menyinggung bagianbagian dari hak-hak asasi atau hakhak yang disetarakan dengannya.

c. b. Di Indonesia, gagasan mengenai penerapan pengaduan konstitusional adalah suatu kebutuhan kebutuhan yang mendesak. Sama seperti apa yang mendasari munculnya pengaduan konstitusional di beberapa negara, paham konstitusionalisme menjadikan pengaduan konstitusional sebagai konsekuensinya. Selain sebagai konsekuensi dari paham konstitusionalisme, pengaduan konstitusional ini juga adalah sebuah keniscayaan untuk diterapkan. Hal ini dikarenakan begitu banyaknya perkara yang tergolong pengaduan konstitusional yang diterima oleh Mahkamah Konstitusi Republik Indonesia, dimana akhirnya dinyatakan tidak dapat diterima oleh Mahkamah Konstitusi dikarenakan bukan wewenang mereka.

d. Dalam penerapan pengaduan konstitusional di Indonesia, tentu saja hal tersebut tidak terlepas dari hambatan dan peluang yuridis yang ada. Pasal 24C ayat (1) dan (2) UUD 1945 telah secara limitatif menentukan kewenangan Mahkamah Konstitusi, maka penambahan kewenangan hanya mungkin dilakukan dengan melakukan perubahan terhadap ketentuan UUD 1945 dimaksud.

\section{Daftar Bacaan}

\section{Buku}

M.D. Moh. Mahfud. Demokrasi dan Konstitusi di Indonesia, Rineka Cipta, Jakarta, 1993

Republik Indonesia, Mahkamah Konstitusi, Cetak Biru Membangun Mahkamah Konstitusi Sebagai Institusi Peradilan Konstitusi Yang Modern Dan Terpercaya, Jakarta, 2004

\section{Majalah}

M.D. Moh. Mahfud, "Reformasi Peradilan harus dituntaskan", Newsletter KHN, Vol. 8, No. 4, Juli-Agustus 2008

\section{Makalah}

Palguna. I Dewa Gede, Pengaduan Konstitusional (constitutional complaint) dan Perlindungan Hak-hak Konstitusional Warga Negara, disampaikan pada Seminar "Pengaduan Konstitusional (Constitutional Complaint) dan Kewenangan Mahkamah Konstitusi Republik Indonesia dalam Penegakan Hak-Hak Konstitusional Warga Negara" yang diselenggarakan oleh Sekretariat Jenderal dan Kepaniteraan Mahkamah Konstitusi bekerjasama dengan Fakultas Hukum Universitas Udayana, 12 Desember 2009 


\section{Konstitusi}

Konstitusi Republik Federal Jerman;

Undang-Undang Dasar Republik Indonesia 1945.

\section{Peraturan Perundang-undangan}

Undang-Undang Mahkamah Konstitusi FederalJerman(BundesverfassungsgerichtsGesetz, biasanya disingkat dengan BVerfGG);

Undang-Undang Republik Indonesia Nomor 24 Tahun 2003 tentang Mahkamah Konstitusi;

Undang-Undang Republik Indonesia Nomor.4 Tahun 2004 tentang Kekuasaan Kehakiman.

\section{Putusan Mahkmah Konstitusi}

Kumpulan keputusan-keputusan Mahkamah Konstitusi Federal (BverfGE)

Putusan Mahkamah Konstitusi Republik Indonesia Nomor : 016/PUU-I/2003;

Putusan Mahkamah Konstitusi Republik Indonesia Nomor : :061/PUU-II/2004;

Putusan Mahkamah Konstitusi Republik Indonesia Nomor : :004/PUU-III/2005;

Putusan Mahkamah Konstitusi Republik Indonesia Nomor : :001/PUU-IV/2006. 